\title{
Preparation of Cicer Artienium Amylase Loaded BSA Nanoparticles and Their Bioproteolysis to be Used as Detergent Additive
}

\author{
Kirti Rani", Chanchal Chauhan \\ Amity Institute of Biotechnology, Amity University, India
}

Copyright (C) 2015 by authors, all rights reserved. Authors agree that this article remains permanently open access under the terms of the Creative Commons Attribution License 4.0 International License

\begin{abstract}
Cicer aritenium is rich source of amylase and used for extraction of amylase. Amylases are known for their industrial application in food, pharmaceutical, detergent, textile and leather industries. The extracted amylase was encapsulated into biochemically engineered BSA nanoparticles with butanol through glutaraldehyde by desolavtion method. BSA was chosen as a biocompatible matrix used for the binding of amylase where $77.6 \%$ of enzyme encapsulation was achieved. This binding was lead to enhancing the thermal stability at $72^{\circ} \mathrm{C}$ for 6 hours and storage stability at $4^{\circ} \mathrm{C}$ of bound enzyme for 16 months as compared to free enzyme whose thermal stability at $72^{\circ} \mathrm{C}$ only for 15 minutes and storage stability only for 24 hours day were found. However, studied thermal stability, storage stability and $\%$ of encapsulation for maximal activity for encapsulated enzyme was found to be at remarkably higher as compared to free enzyme which increased the industrial viability of amylase after immobilization. Characterization of prepared nanoparticles was done by Dynamic Light scattering (DLS) and Scattering Light Microscopy (SEM). Observed size of enzyme loaded nanoparticles was observed in the range of $56 \mathrm{~nm}$ to $107.4 \mathrm{~nm}$. Bioproteolysis of enzyme loaded BSA nanoparticles was performed by alkaline protease $(10 \mathrm{U}, 15 \mathrm{U}, 20 \mathrm{U}, 25 \mathrm{U}, 30 \mathrm{U}, 35 \mathrm{U}, 40 \mathrm{U}$, $45 \mathrm{U})$ for sustained and controlled release of encapsulated amylase from prepared nanoparticles. And, further, their application was studied with detergents powder (Aerial, Surf Excel, Wheel and Tide) for washing of tough stained cloths pieces having chosen stains of coffee, tea, pomegranate and turmeric. These strains are found to be difficult to vanish in one simple wash. But, this cost effective bio-active enzyme loaded BSA nanopreaparation were found to be effective in washing with chosen detergents for quick and efficient washing with absolute clear visible results as compared to the results when washing of stained cloths pieces was done with detergents only.
\end{abstract}

Keywords Cicer Aritenium, Amylase, Bovine Serum Albumin, Nanoparticles, Glutaraldehyde, Encapsulated, Desolvation, Dynamic Light Scattering (DLS) Scanning Electron Microscopy (SEM), Bioproteolysis

\section{Introduction}

Amylases are starch-degrading enzymes that require calcium ions $\left(\mathrm{Ca}^{2+}\right)$ for their activity, structural integrity and stability. ${ }^{[1]}$ Amylases have most important industrial applications in conversion of starch to sugar syrups and production of cyclodextrins for the pharmaceutical industry. ${ }^{[2]}$ The amylase mediated hydrolysis is preferred for acid hydrolysis in starch processing industry due to its reaction specificity, product stability, lower energy requirements and minimizing the neutralization steps ${ }^{[3]}$ Due to the increasing demand of raw starch degrading amylases, various cost effective production techniques were going to developed according to respective industry needs. ${ }^{[4]}$ Enzymes are the biocatalyst which have effective and conventional role in cosmetics preparation, paper industry, textile industry, food industry, pharmaceutical industry and laundry industries. ${ }^{[6]}$

Application of synergic correlation of biotechnology and nanotechnology was used to develop new advanced methods to immobilize the enzymes on various nanomaterials which reduce the industrial cost. ${ }^{[7,8]}$ Colloidal albumin has been considered as potential carriers for site specific drug delivery and various natural polymers are Chitosan Gelatin Sodium alginate, synthetic polymers include Polylactides(PLA), Polyglycolides(PGA), Poly(lactide co-glycolides)(PLGA), Polyanhydrides, Polyorthoesters, Polycyanoacrylates, Polycaprolactone, Poly glutamic acid, Poly(N-vinyl pyrrolidone), Poly(methyl methacrylate) were also chosen for encapsulation of drugs and enzymes. ${ }^{[9]}$

Nanotechnology-driven biocatalysts have laurel interest to immobilize any chemical and biological components on various potential biocompatible nanomaterials for excellent particle mobility. ${ }^{[10,11]}$ As well as, drugs and antibodies loaded nanoparticles and very small sized nanomaterials can be used to target antigens or bio-markers in combating cancer cells. ${ }^{[12,13]}$ Enzyme immobilization into nanomaterials was divided into two categories: nonspecific or specific and hence, non-specific immobilization methods generally include adsorption, non-specific covalent binding, 
entrapment and encapsulation. ${ }^{[14,15]}$ Previously, amylase was also immobilized within aqueous core colloidosomes whose shell comprising polymer latex particles of diameter 153 $\mathrm{nm}{ }^{[16]} \mathrm{Cu}^{2+}$ chelated poly(ethylene glycol dimethacrylate-n-vinyl imidazole) matrix was used for immobilization of amylase via adsorption with $70 \%$ of retention of activity after immobilization. ${ }^{[17]}$ Poly (hydroxyethyl methacrylate-co-glycidyl methacrylate) has $76 \%$ of retention of activity of amylase after immobilization as well as amylase was also encapsulated with in alginate capsules with $70 \%$ of retention of activity. ${ }^{[18-20]}$

DEAE-cellulose was also chosen for enzyme entrapment within alginate beads with $88.9 \%$ of enzyme retention after immobilization and within hydrophilic silica gel with $92.3 \%$ immobilization. ${ }^{[21]}$ Other nanotechnological techniques like desolvation, emulsification, thermal gelation, nano-spray drying, nab-technology and self-assembly that have been investigated for fabrication of albumin nanoparticles. ${ }^{[22]}$ Among the potential methods, emulsion formation, desolvation, or coacervation methods are commonly preferred for nanopreparation. Human serum albumin based emulsion techniques was carried out to stud the influenced protein concentration, emulsification time, stirring strength, thermal stabilization and aqueous phase type. ${ }^{[24]}$ Scientists are still improving present technologies that favour immobilization of industrial important enzymes into eco-friendly and biocompatible nanomaterials. ${ }^{[25]}$

Amylases are ubiquitous enzymes produced by plants, animals and microbes, where they play significant role in degradation of carbohydrate.$^{[25,26]}$ Previously, amylase was immobilized by physical adsorption onto silica, alumina, chitin, tannin sepharose, Ionic binding on Amberlite IR-120, Dowex50W ion exchange resins, DEAE-Cellulose DE-52, entrapment commonly on Calcium Alginate beads and egg albumin. ${ }^{[22,24,26,28]}$

In present work, bovine serum albumin was used as a biocompatible and non-toxic matrix for encapsulation of Cicer aritenium amylase which was biochemically engineered by chemical modifiers such as butanol and glutaraldehyde as a cross-linking agent. ${ }^{[29-35]}$ Sustained and controlled release of loaded amylase was carried out by using varying units of alkaline protease. ${ }^{[21,36,38-41]}$ Characterization of prepared enzyme loaded bovine serum albumin nanoparticles was done by DLS (Dynamic Light Scattering) and SEM (Scanning Electron Microscope). Gradual breakdown of encapsulated amylase form biochemically modified BSA nanoparticles was mediated by using varying units of alkaline protease (10 U, $15 \mathrm{U}, 20$ $\mathrm{U}, 25 \mathrm{U}, 30 \mathrm{U}, 35 \mathrm{U}, 40 \mathrm{U}, 45 \mathrm{U}, 50 \mathrm{U})$ to study their bioproteolysis. $^{[41]}$ The studied sustained release of bound amylase from biochemically modified bovine serum albumin has widened the industrial application due to having increased stability and sustained usability as compared to free enzyme. ${ }^{[42,43]}$ Kinetic parameters of free and encapsulated amylase were studied for their optimal $\mathrm{pH}$ (1.5-11.5), incubation time (20mins-4hours), substrate concentration $(0.50 \%-1.5 \%), \mathrm{CaCl}_{2}$ concentration $(1 \%-10 \%)$ and temperature $\left(5^{\circ} \mathrm{C}-100^{\circ} \mathrm{C}\right)$ by carrying out the amylase activity by dinitrosalicyclic acid method. ${ }^{[15,18,21,43-45]}$

Hence, their bioproteolysis application was study for efficacy in washing of the stained clothes with chosen detergents powder (Aerial, Surf Excel, Wheel and Tide) for washing of tough stained cloths pieces having routine stains of coffee, tea, pomegranate and turmeric. ${ }^{[35,40]}$

\section{Materials and Methods}

\section{Extraction of Amylase}

Seedlings of Cicer aritenium were homogenized by adding 4-6 $\mathrm{ml}$ of 0.05 $\mathrm{M}$ sodium phosphate buffer ( $\mathrm{pH} 7.0$ ) per gram of seeds and centrifuged for 15 minutes at $4^{\circ} \mathrm{C}$ at $5000 \mathrm{rpm}$. Discard the pellet and collect the supernatant which contained crude amylase extract and then stored at $4^{\circ} \mathrm{C}^{[21,41,44,51]}$

\section{Amylase Assay}

Enzyme assay was done by using $1 \%(\mathrm{w} / \mathrm{v})$ starch solution in which $0.5 \mathrm{ml}$ enzyme extract was added and incubated at $37^{\circ} \mathrm{C}$ for 20 minutes. $2 \mathrm{ml}$ of dinitrosalicylic acid was added and the mixture was boiled at $100^{\circ} \mathrm{C}$ for 5 minutes. Absorbance was taken at $570 \mathrm{~nm} .^{[16,15,43,44,51]}$

\section{Ammonium Sulphate Precipitation and Dialysis}

$80 \%$ of ammonium sulphate precipitation was done by adding ammonium sulphate salt in to crude enzyme extract with 25 minutes of stirring. After the complete addition of ammonium sulphate salt was stirred for 30 minutes and incubated for 1 hour and centrifuged for 25 minutes at $4^{\circ} \mathrm{C}$ at $10000 \mathrm{rpm}$. Supernatant was discarded and the pellet was dissolved in $0.05 \mathrm{M}$ sodium acetate buffer $(\mathrm{pH} 3)$ and kept at $-20^{\circ} \mathrm{C}$. Dialysis was done in partially purified enzyme extract by using dialysis tubing which was rinsed with distilled water whose one end was clutched with a thread and $10 \mathrm{ml}$ of sample was poured into it and other end was also clutched called dialysis bag which was placed in $10 \mathrm{mM}$ Tris $\mathrm{HCl}$ buffer. It was incubated for 24 hours at $4^{\circ} \mathrm{C}$. The pure sample was poured out after incubation and kept at $4{ }^{\circ} \mathrm{C} .{ }^{[45,47]}$

\section{Study of Kinetic Properties}

The free enzyme and immobilized enzyme were characterized for their different kinetic properties i.e. effect of $\mathrm{pH}$, effect of temperature, effect of incubation time, effect of $\mathrm{CaCl}_{2}$ concentration and effect of substrate concentration. The effect of $\mathrm{pH}$ on activity of free and immobilized enzymes was studied by performing enzyme assay at different $\mathrm{pH}$ using phosphate buffer. $\mathrm{pH}$ was varied from 2 to 12. The effect of time on the activity of free and immobilized enzyme was studied by performing the enzyme assay at different time (5 minutes-25 minutes). Optimal substrate concentration needed for maximal enzyme activity for free and immobilized enzymes which were estimated by incubating the reaction mixture at different concentrations of starch solution $(0.25 \%-1.50 \%)$. The effect of $\mathrm{CaCl}_{2}$ on 
activity for free and encapsulated enzymes was studied by performing the enzyme assay at different concentrations (2\%-10\%). Optimal temperature needed for free and encapsulated enzyme for maximal activity was studied by incubating the reaction mixture for 15 minutes at different temperature $\left(10^{\circ} \mathrm{C}-100^{\circ} \mathrm{C}\right)$. These kinetic properties of enzyme were determined by performing dinitrosalicyclic acid. ${ }^{[18,21,29]}$

\section{Preparation of Enzyme Loaded BSA Nanoparticles}

Nanoparticles were prepared by desolvation method given by Sailaja A. et al., 2012 and Rani K, 2012 with slight modifications. Purified enzyme was dissolved in n-butanol and was added dropwise to the BSA solution kept under the magnetic stirrer till the formation of opalescent suspension. After this, 25\% glutaraldehyde was added for crosslinking of enzyme in prepared reaction mixture. This reaction solution was kept overnight with stirring. The reaction solution was centrifuged at $5000 \mathrm{rpm}$ at $4^{\circ} \mathrm{C}$ for 20 mins. The supernatant was removed and the pellets were re-dispersed in chilled acetone in bath sonicator for $12 \mathrm{mins}$. Next day, it was centrifuged at $5000 \mathrm{rpm}$ at $4^{\circ} \mathrm{C}$ for 20 minutes. Supernatant was removed and pellet was washed with cold diethyl ether and acetone. The pellet was re-dispersed into acetone in bath and sonicated for 12 minutes. Enzyme assay was done in supernatant to know the \% of encapsulation of amylase in biochemically activated BSA (bovine serum albumin) nanoparticles. ${ }^{[14,22,41,44]}$

\section{\% of Enzyme Encapsulation}

The $\%$ of encapsulated enzyme was calculated by determining the residual enzyme activity from reaction mixture in which encapsulation of amylase was done into prepared BSA (bovine serum albumin) nanoparticles. Amylase assay was performed by using dinitrosalicylic acid. ${ }^{[20,45-48]}$

$\%$ of encapsulated enzyme $=$

$$
\frac{\text { Specific activity of encapsulated enzyme }}{\text { Specific activity of free enzyme }} \times 100
$$

\section{Characterization of Enzyme Loaded BSA Nanoparticles}

The prepared amylase loaded nanoparticles were subjected for characterization under Dynamic Light Spectroscopy (DLS) and Scanning Electron Microscope (SEM) for determination of their particle size. ${ }^{[21,45,46,51,54]}$

\section{Alkaline Protease Mediated Bioproteolysis}

$2 \mathrm{mg}$ amylase loaded biochemically activated BSA (bovine serum albumin) nanoparticles were taken in test tubes with reaction solution of different units of alkaline protease (10U, 15U, 20U, 25U, 30U, 35U, 40U and $45 \mathrm{U})$ which is considered excellent protease used with detergents in washing for combating washing conditions such as $\mathrm{pH}$, temperature and salt effect. ${ }^{[31-34]}$ The reaction tubes were incubated at $4^{\circ} \mathrm{C}$ for overnight. Next day enzyme assay was done at $570 \mathrm{~nm}$ using dinitrosalisylic acid method and this study with different units of alkaline protease was done from 1st day till 7th day. ${ }^{[40,53-54]}$

\section{Application of Enzyme Loaded BSA Nanoparticles in Fabric Desizing}

Cicer aritenium amylase loaded BSA nanopreparation was used in removal of tough-dry-routine stains of coffee, tea, pomegranate and turmeric to study washing with chosen detergents powder (Aerial, Surf Excel, Wheel and Tide). The chosen strained cloth pieces was washed with chosen international brands of detergents such as Ariel, Surf Excel, Wheel and Tide only and with the prepared alkaline protease mediated bioactive mixture of Cicer aritenium amylase bound biochemically engineered BSA nanopreparation along with chosen detergent powders. Stained cloths pieces having dry strains of coffee, tea, pomegranate and turmeric were chosen and dipped in reaction solution of $2 \mathrm{mg}$ of prepared bioactive enzyme bound BSA nanopreparation with $1 \mathrm{ml}$ of different chosen washing powder solution in petri plates. Each sample of stained cloths was tested with all the four chosen detergents only and with the combination mixture of bioactive enzyme bound chemically modified BSA nanoprearation for carrying out its comparative washing study for desizing of fabrics. ${ }^{[35}$, $40,50,51]$

\section{Result and Discussion}

\section{$\%$ of Encapsulation}

Cicer aritenium amylase loaded biochemically engineered BSA nanoparticles has $77.6 \%$ retention of enzyme activity whose result was found to be similar to previous study in which Cicer arietinum amylase had $81.34 \%$ retention activity of enzyme into emulsified bovine serum albumin nanoparticles ${ }^{[54]}$ and lesser than $99 \%$ of Glucose oxidase was immobilized in bovine serum albumin nanoparticle using mustard oil. ${ }^{[46]}$ As well as, \% of encapsulation of Pearl millet was also previously reported in the range of 79.7 to $81 \%$ whose finding were also comparable with our study. ${ }^{[51,53,54]}$

\section{Characterization of Enzyme Loaded BSA Nanoparticles}

The prepared enzyme loaded bovine serum albumin anoparticle in test mixture was characterized by observed first sharp peak which confirmed size of nanoparticles in the approximate range of $2 \mathrm{~nm}$ to $5 \mathrm{~nm}$ followed by second peak for having size $9 \mathrm{~nm}$ to $11 \mathrm{~nm}$ and third two coherent peaks for having size in the range of $90 \mathrm{~nm}^{[51]}$ to $700 \mathrm{~nm}^{[54]}$ using Dynamic Light Spectroscopy (DLS) (Fig 1). The observed size of enzyme loaded bovine serum albumin nanoparticles under Scanning Electron Microscope was found to be in the range of $56 \mathrm{~nm}$ to $107.4 \mathrm{~nm}$ which were found to be comparable with previous observations whose observed nanoparticle size was in range of $50 \mathrm{~nm}$ to $700 \mathrm{~nm} .^{[51,54]}$ Fluorescence was also observed in prepared nanoparticles due to formation of diene adduct complex during covalent coupling with enzyme due to activation of aromatic amino acids residue e.g. tryptophan, phenyalanine and trysoine amino acid residue by using of glutaraldehyde (Fig 2). ${ }^{[46]}$ 


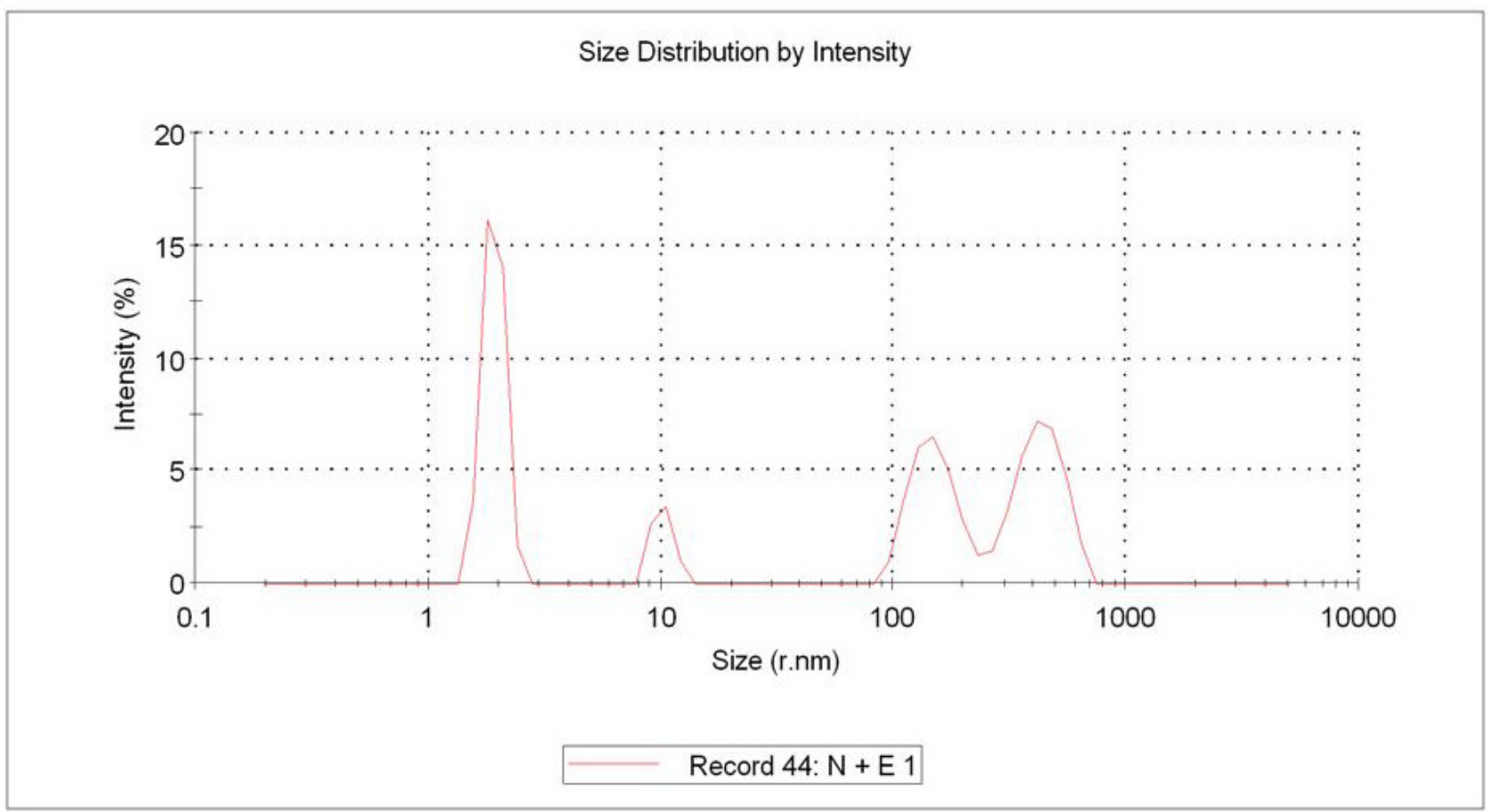

Figure 1. DLS of enzyme loaded BSA nanoparticles

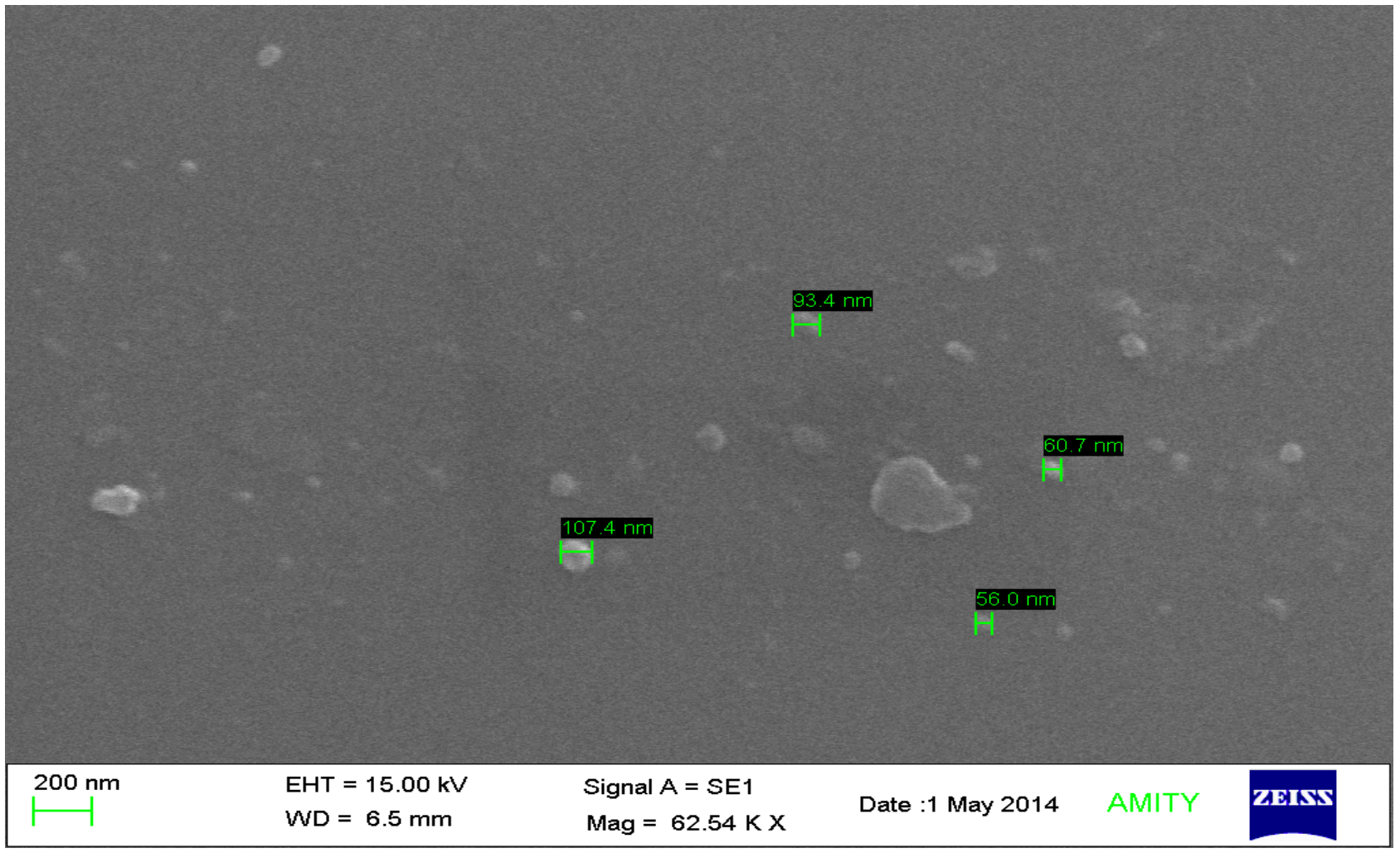

Figure 2. SEM of enzyme loaded BSA nanoparticles 


\section{Studied Kinetic Properties}

Table 1. Studied Kinetic Parameters of free and encapsulated amylase

\begin{tabular}{|c|c|c|}
\hline Kinetic Parameters & Free amylase & $\begin{array}{c}\text { Encapsulated } \\
\text { amylase }\end{array}$ \\
\hline Optimal pH & 8.0 & 6.0 \\
\hline Optimal Temperature & $50^{\circ} \mathrm{C}$ & $65^{\circ} \mathrm{C}$ \\
\hline Thermal Stability at $72^{\circ} \mathrm{C}$ & 15 minutes & 6 hours \\
\hline $\begin{array}{c}\text { Optimal time of incubation } \\
\text { Optimal Substrate } \\
\text { concentration }\end{array}$ & 15 minutes & 20 minutes \\
\hline Optimal CaCl ${ }_{2}$ concentration & $8 \%$ & $1.25 \%$ \\
\hline Storage stability at $4^{\circ} \mathrm{C}$ & Up to 24 hours & Up to 16 months \\
\hline
\end{tabular}

Optimal pH was observed 6.0 encapsulated amylase while it was 8.0 for free amylase whose results were same as reported in previous studies. ${ }^{[51,54]}$ Optimal incubation time for free enzyme was found to be at 15 minutes and 20 minutes was observed for encapsulated enzyme whose results were same as per previous findings ${ }^{[51,54]}$ Optimal substrate concentrations of free enzyme and encapsulated enzyme was found to be $1.0 \%$ and $1.25 \%$ respectively for both by varying starch concentration from $1 \%-1.5 \%$ whose results were also remarkably same as that of earlier reports. ${ }^{[51-54]}$ Optimal $\mathrm{CaCl}_{2}$ concentration for maximal amylase activity for free and encapsulated amylase was found to $8 \%$ and $4 \%$ respectively whose results were exact similar to previous reports. ${ }^{[51,54]}$ Optimal temperature for maximal activity for free enzyme and encapsulated enzyme was observed $50^{\circ} \mathrm{C}$ and $65^{\circ} \mathrm{C}$ respectively whose results were also similar to previous observations. ${ }^{[51,54]}$ It was also found that after encapsulation, thermal stability and storage stability were enhanced for bound enzyme (at $72^{\circ} \mathrm{C}$ for 6 hours and 16 months respectively) as compared to free enzyme (at $72^{\circ} \mathrm{C}$ for 15 minutes and 24 hours only respectively) which were also fairly similar to previous findings (Table 1). ${ }^{[51-54]}$

\section{Bioproteolysis Study}

Bioproteolysis of Cicer aritenium amylase loaded BSA nanoparticles was performed by incubating $2 \mathrm{mg}$ of enzyme loaded BSA nanoparticles with alkaline protease $(10 \mathrm{U}, 15 \mathrm{U}$, $20 \mathrm{U}, 25 \mathrm{U}, 30 \mathrm{U}, 35 \mathrm{U}, 40 \mathrm{U}, 45 \mathrm{U})$ overnight at $4^{\circ} \mathrm{C}$. The study was carried out for consecutive 8 days and $30 \mathrm{U}$ and 40 $\mathrm{U}$ of alkaline protease were found to be effective to achieve gradually controlled and sustained release of encapsulated Cicer aritenium amylase form BSA(bovine serum albumin) nanoparticles (Fig 3). ${ }^{[35,40]}$ First 4 days, the release of the enzyme was negligible but with the time, it was gradually increased up to over the next 2 days. ${ }^{[46]}$ From $7^{\text {th }}$ day onwards, the enzyme activity was slightly increased with noticeable change till $8^{\text {th }}$ day where whole bound enzyme was released into delivery system. ${ }^{[51,54]}$

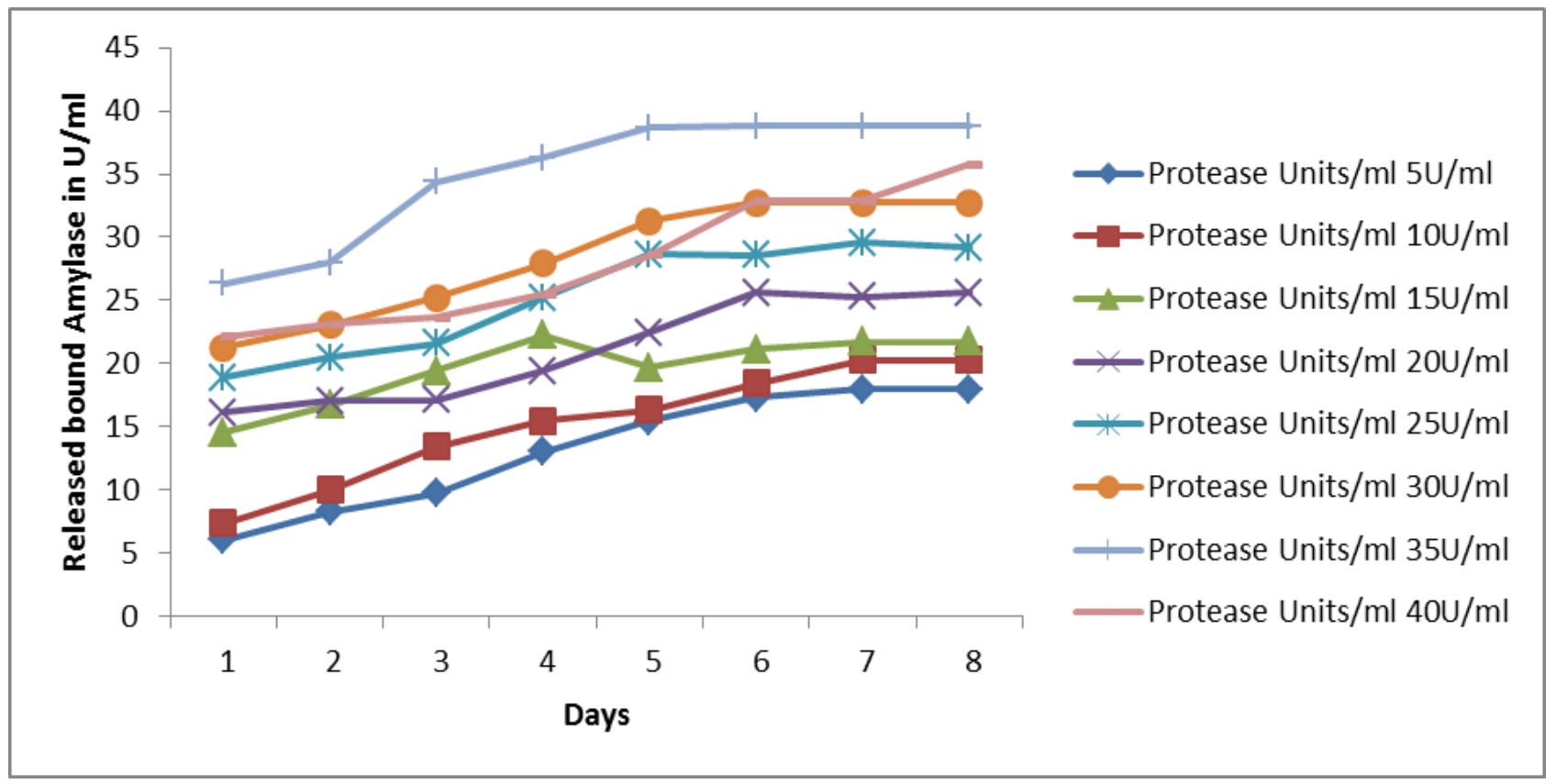

Figure 3. Bioproteolysis of enzyme loaded BSA nanoparticles with different units of alkaline protease (10U, 15U, 20U, 25U, 30U, 35U, 40U, 45U, 50U) for controlled release of encapsulated Cicer aritenium amylase 


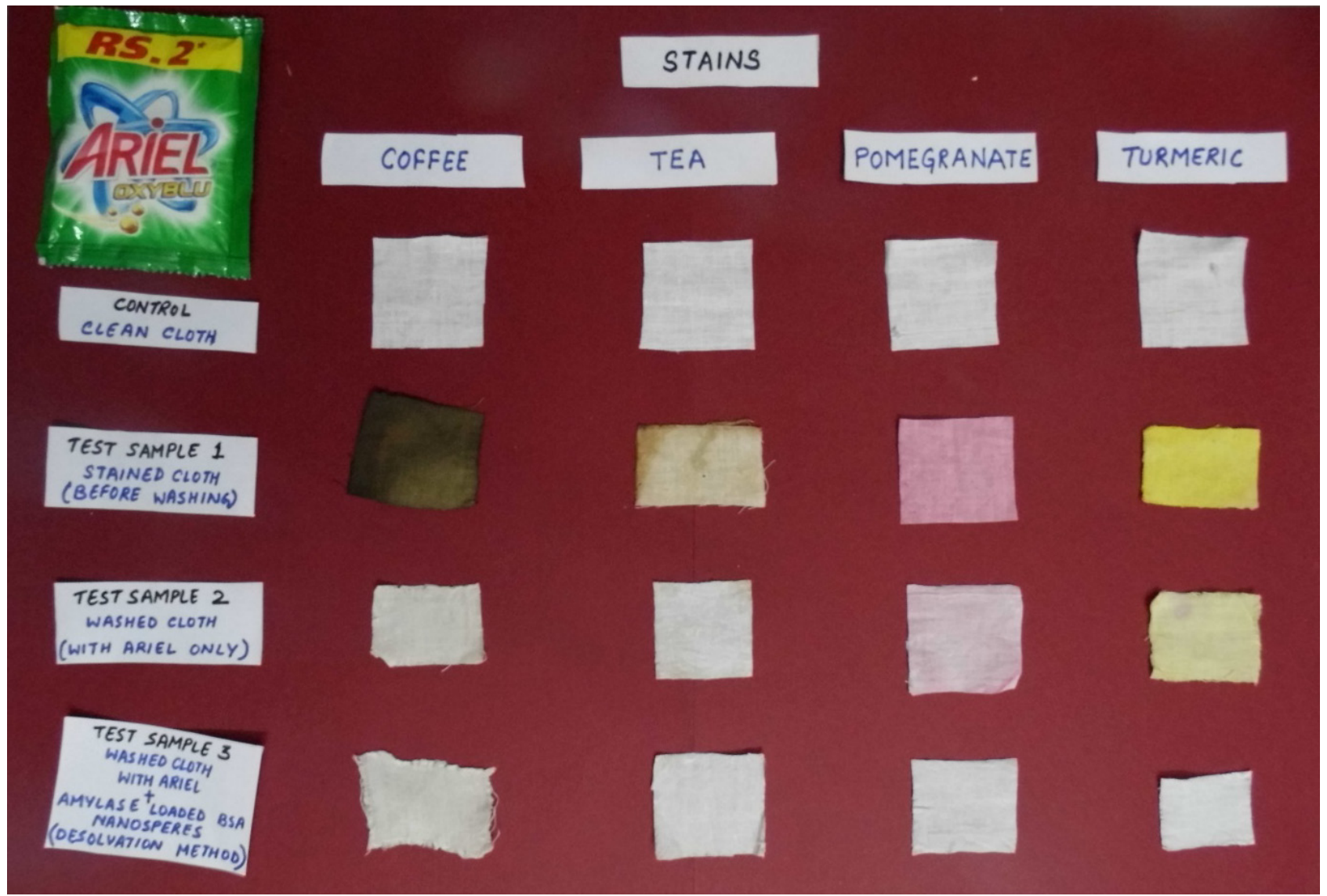

Figure 4. Washing results of stained cloth pieces with Ariel only and Ariel with Cicer aritenium amylase loaded BSA nanoparticles

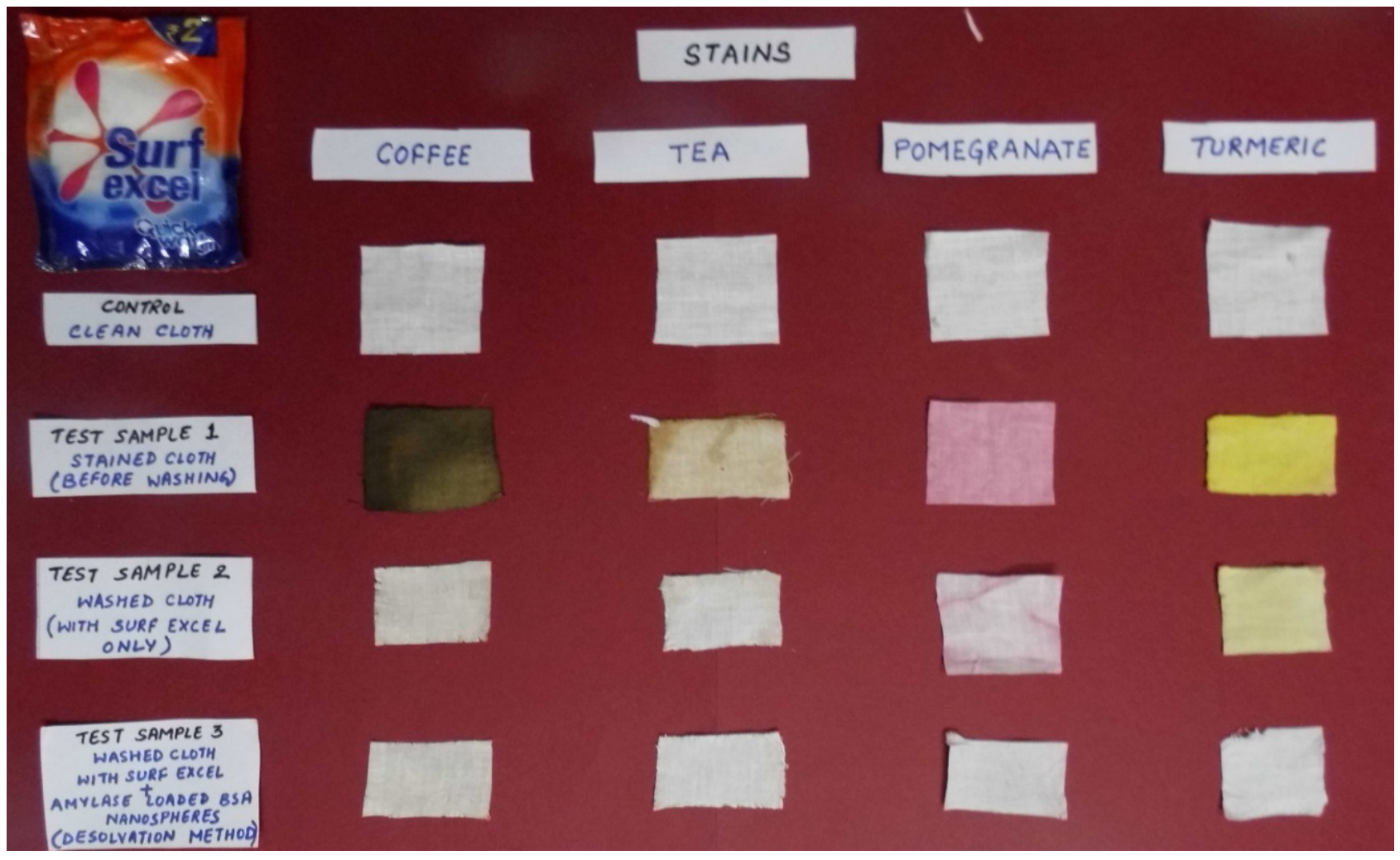

Figure 5. Washing results of stained cloth pieces with Surf Excel only and Surf Excel with Cicer aritenium amylase loaded BSA nanoparticles 


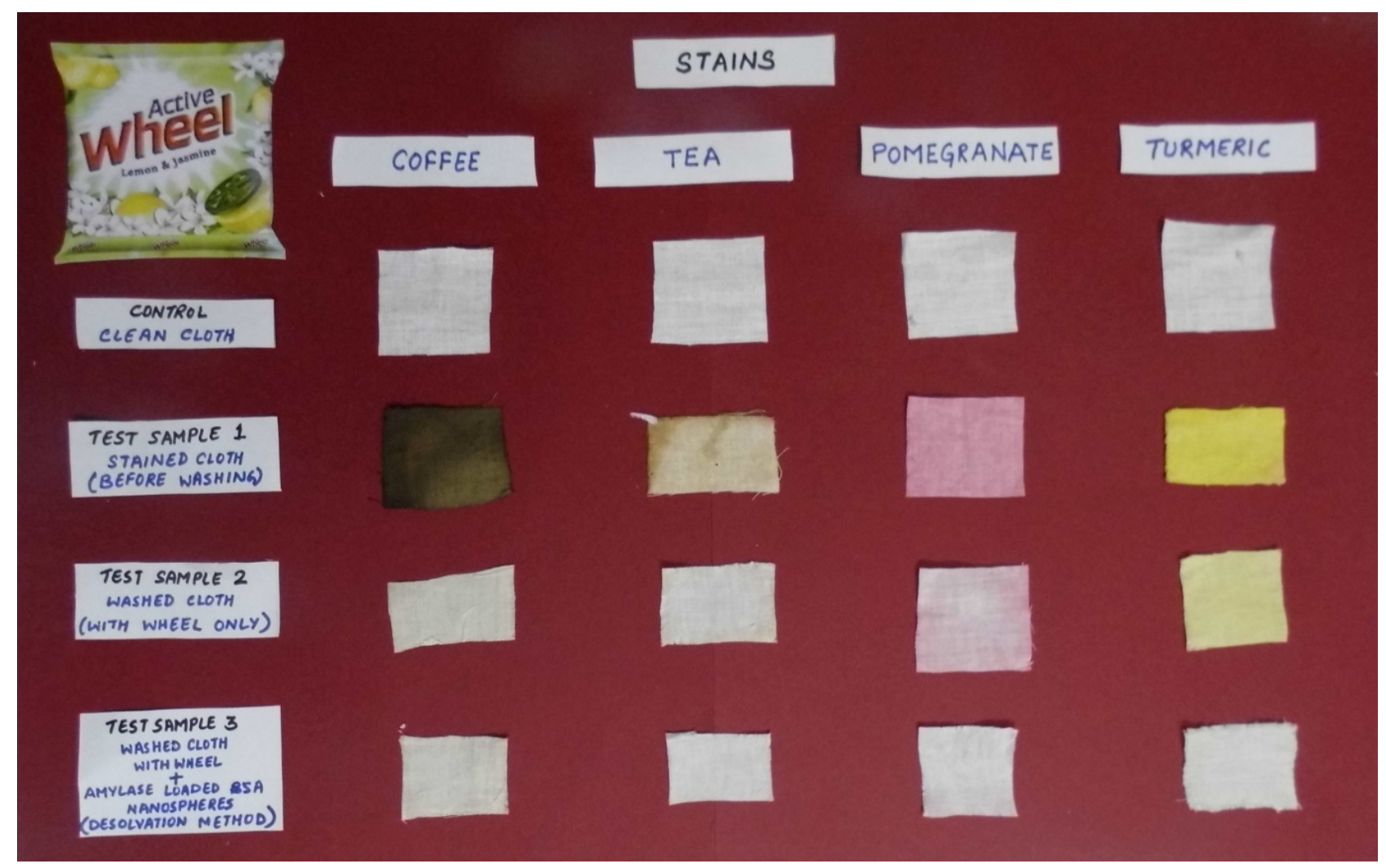

Figure 6. Washing results of stained cloth pieces with Wheel only and Wheel with Cicer aritenium amylase loaded BSA nanoparticles

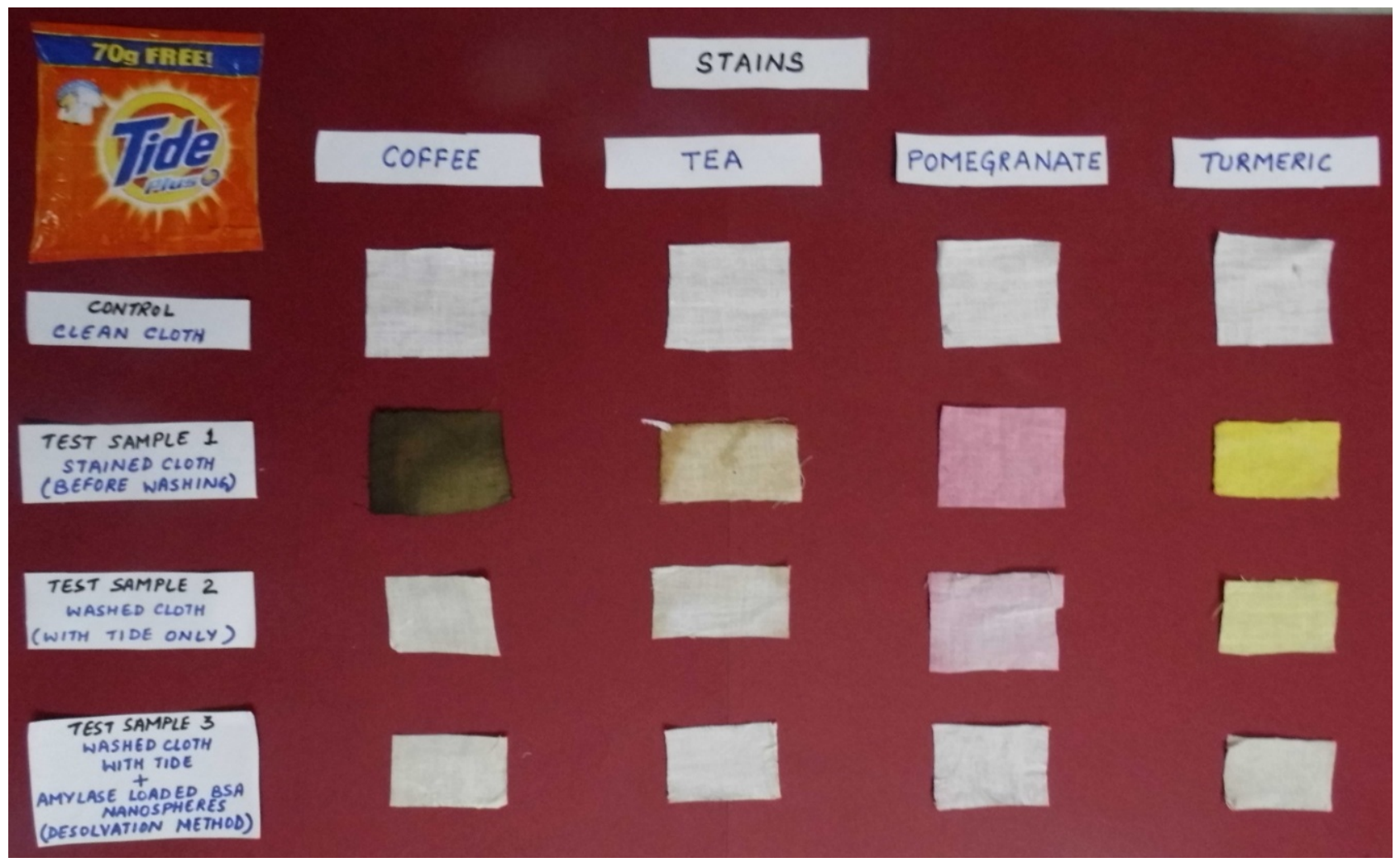

Figure 7. Washing results of stained cloth pieces with Tide only and Tide with Cicer aritenium amylase loaded BSA nanoparticles 


\section{Applications of Enzyme Loaded BSA Nanoparticles in Fabric Desizing}

The application of prepared enzyme loaded BSA nanoparticles was studied with four chosen different samples of detergent solutions (Ariel, Tide, Surf excel and Wheel) to remove dry tough stains of chosen foodstuffs (coffee, tea, pomegranate and turmeric) from stained cloth pieces (Fig 4-7). The bio-active enzyme bound BSA nanoparticles with alkaline protease solution along with chosen detergent powder was used for washing to vanish dry tough from stained cloth pieces during its fabric desizing to study the washing efficacy of detergents powder as eco-friendly and cost effective detergent additive. Because these routine tough stains were usually not vanished completely if washed with the chosen detergent samples in one wash even when they were soaked in lukewarm water. Among the four chosen samples of commercially available detergent powder, Ariel detergent with alkaline protease mediated enzyme bound BSA nanoparticles solution was showed best and well visible washing results as compared to others followed by Surf excel, Wheel and Tide respectively (Fig 4, 5, $6 \& 7$ respectively) which were fairly comparable to previous washing analysis. ${ }^{[51-55]}$ Hence, the use of this cost effective and eco-friendly enzyme loaded BSA nanoparticles with effective alkaline protease units along with detergents may have advantages in desizing of stained fabrics to enhance washing efficacy to reduce operational cost and time without any requirement of expertise or any functional washing step.

\section{Conclusions}

Cicer arietinum amylase was encapsulated into biochemically activated BSA (bovine serum albumin) nanoparticles by desolvation method with $77.6 \%$ of enzyme encapsulation. Even after the encapsulation, storage and thermal stability of enzyme was also increased which made it more washing efficient biochemically engineered detergent additive as desizing catalyst to vanish the dried and tough stains completely form cloths pieces when used with chosen detergents. ${ }^{[50,51,54,55]}$ The observed size of prepared enzyme loaded BSA nanoparticles was found to be in the range of 56 $\mathrm{nm}$ to $107.4 \mathrm{~nm}$ by Scanning Electron Microscope (SEM). Fluorescence was also noticed in amylase loaded BSA nanoparticles due to formation of diene adduct complex which was introduced due to activation of aromatic amine acid residues via the glutaraldehyde coupling. The result of alkaline protease mediated bioproteolysis was showed that $30 \mathrm{U}$ and $40 \mathrm{U}$ of alkaline protease was found to be effective in gradually controlled and sustained release of bound enzyme from BSA nanoparticles. The encapsulated Cicer aritenium amylase was found to have increase storage stability for 16 months when stored at $4^{\circ} \mathrm{C}$ and excellent reproducibility and thermal stable up to $72^{\circ} \mathrm{C}$ for 6 hours which was remarkably higher as compared to free enzyme with storage stability for 24 hours only and having thermal stability at $72^{\circ} \mathrm{C}$ for 15 minutes only. Hence, this controlled bioproteolysis study of prepared Cicer aritenium amylase loaded bovine serum albumin nanoparticles may have fairly good industrial application in detergent industries as a eco-friendly and cost effective bio-active additive for enhancing leaching and desizing of stained fabric to treat raw cellulose, starch, leather and wood pulp along with bioprocessing of various types of natural and synthetic fabrics too.

\section{REFERENCES}

[1] Bordbar AK, Omidiyan K and Hosseinzadeh R. (2005) Study on interaction of a-amylase from Bacillus subtilis with cetyl trimethylammonium bromide. Colloids Surf. B: Biointerfaces, 40:67-71.

[2] Maarel MJ, Veen B, Uitdehaag JCM, Leemhuis H and Dijkhuizen L. (2002) Properties and Applications of Starch-Converting Enzymes of the Amylase Family. J. Biotechnol. 94:137-155.

[3] Satyanarayana T, Rao JLUM and Ezhilvannan M. (2005) Alpha-amylases: in Enzyme Technology, A. Pandey, C. Webb, C.R. Soc- col, C. Larroche (Eds.), Asiatech Publishers Inc., New Delhi, India. Pp: 189-220.

[4] Burhan A, Nisa U, Gokhan C, Omer C, Ashabil A and Osman G. (2003) Enzymatic Properties of A Novel Thermostable, Thermophilic, Alkaline And Chelator Resistant Amylase from an Alkaliphilic Bacillus sp. Isolate ANT-6. Process. Biochem. 38; 1397-1403.

[5] Wilhelm T and Volker K, Immobilized enzymes: crystals or carriers? Elsevier Science. 1999, Vol-17: PII: S0167-7799(99)01322-0 1999.

[6] Nisha S, Arun K S and Gobi N, A Review on Methods, Application and Properties of Immobilized Enzyme, Che Sci Rev Lett. 2012, 1(3); 148-155

[7] Rani K, Immobilization of Glycine max amylase onto variety of chlorinated and Nintrated fabrics (silk, nylon and cotton). GSTF Int J Biosci. 2013, 2(2): 8-12.

[8] Rani K, A brief review on convergence of diversifying fields of nanotechnology and bio-informatics as an advanced revolutionized device for betterment of humankind. Int $J$ Pharma Res Health Sci. 2014, 2(3): 197-202.

[9] Nagavarma B V N., Hemant K.S., Yadav., Ayaz A., Vasundhra L.S., Shivkumar H.G., (2012) Different techniques for preparation of polymeric nanoparticles- A review, Asian Journal of Pharmaceutical and Clinical Research, Vol 5, Suppl 3, 16-23.

[10] Wang P, Nanoscale Biocatalyst System. Curr Opin Biotechnol, 2006, 17(6):574.

[11] Rani K, Chauhan C and Kaur H, Potential and automotive applications of nanomaterials in combating cancer and stem cell therapy: An informative overview on nanotherapeutics. $J$ Nanotech and Smart Materials. 2014, 1: 1-6.

[12] Rani K, Chauhan N, Narang J, Jain U and Sharma S, A cost effective immobilization of horseradish Peroxidase nanoparticles on to Easy-To-Prepare activated plasticized 
polyvinyl-chloride vial and its application. J Nanomedicine Res. 2015, 2(1): 1-5.

[13] Letant SE, Hart BR, Kane SR, Hadi MZ, Shields SJ, Reynolds JG, Enzyme immobilization on porous silicon surfaces. Adv Mater. 2004, 16: 689-693.

[14] Rani K, Emulsified Entrapment of Glycine Max B-amylase into Chemically Modified Bovine Serum Albumin and Study its Applications in Detergents. Int $J$ of Advanced Biotechnol \& Res. 2012, 3(2): 591-595

[15] Keen P H R, Slater N K H and Routh A F. Encapsulation of amylase in colloidosomes. Lamgmuir. 2014, 30(8): 1939-1948.

[16] Kara A., Osman B., Yavuz H., Besirli N., Denizli A., (2005) Immobilization of a-amylase on $\mathrm{Cu}^{2+}$ chelated poly(ethylene glycol dimethacrylate- $n$-vinyl imidazole) matrix via adsorption, React. Funct. Polym. 62 61-68.

[17] Bayramoglu G.,Yilmaz M., Arica MY., (2004) Immobilization of a thermostable a-amylase onto reactive membranes: Kinetics characterization and application to continuous starch hydrolysis, Food Chem. 84 591-599.

[18] Konsoula Z.,Liakopoulou-Kyriakides M., (2006) Starch hydrolysis by the action of an entrapped in alginate capsules a-amylase from Bacillus subtilis, Process Biochem. 41 343-349. 110.

[19] Park D., Haam S, JangK.,Ahn I S., Kim W S.,(2005) Immobilization of starch-converting enzymes on surface-modified carriers using single and co-immobilized systems: Properties and application to starch hydrolysis, Process Biochem.40 53-61.

[20] Rani K, A novel comparative assessment of extracted amylase acitivity in germinating and germinated seeds of Cicer arietinum, Ceci neri and Pisum sativum. Int $J$ Pure \&Applied Sci. 2014, 2(2): 191-193.

[21] Van der Maarel MJEC, van der Veen B, Uitdehaag JCM, Leemhuis H, Dijkhuizen L, Properties and applications of starch converting enzymes of the $\alpha$-amylase family. $J$. Biotechnol. 2002, 94: 137-155.

[22] Sailaja A., Amareshwar P. (2012) Preparation of BSA Nanoparticles by Desolvation Technique Using Acetone as Desolvating Agent. International Journal of Pharmaceutical Sciences and Nanotechnology 5(1):1643-1647.

[23] Elzoghby A, Samy W and Elgindy A. (2012) Albumin-Based Nanoparticles As Potential Controlled Release Drug Delivery Systems. J Controlled Release 157(2):168-182.

[24] Gallo JM, Hung CT and Perrier DG. (1984). Analysis of albumin microsphere preparation. Int. J. Pharm. 22:63-74.

[25] Ricardo R. Morais, Aline M. Pascoal, Samantha S. Caramori, Flavio M. Lopes, and Kátia F. Fernandes, Immobilization of -Amylase onto Luffa operculata Fibers. Enzyme research. 2013, 13(2): 134-140.

[26] Rani K, A novel biodegradation study of toluene driven chemically modified egg albumin preparation for release of entrapped Glycine max amylase with alkaline proteases. Int $J$ Pharmaceutical Res.2014, 6(4): 100-103.

[27] Sharma K R, Preparation of emulsified encapsulated microspheres of egg albumin of bound glucose oxidase and their biodegradation with chymotrypsin. Int J Current Life Sci. 2013, 3(1): 1-4.
[28] Kennedy JF. Enzyme technology. In Biotechnology; Kennedy, J. F., Cabral, J. M. S., Eds.; VCH Publ.-Verlagsgesellschaft mbH: Weinheim, Germany 1987, $7 \mathrm{a}$.

[29] Rani K, Immobilization of vigna mungo amylase into chemically modified bovine serum albumin and its biodegradation. Global J Biotechnol and Biochem Res. 2012, 2(1): 17-20.

[30] Demirkan E, Immobilization of B. amyloliquefaciens $\alpha$-amylase and comparison of some of its enzymatic properties with the free form. Romanian Biotechnological Letters .Tuk J Biol. 2011, 35: 705-712.

[31] Sharma K R, Emulsified encapsulation of vigna radiata amylase into chemically activated bovine serum albumin and its application in detergents. Int J Drug Targets. 2013, 4(2): 135-140.

[32] Rani K, Aqueous two phase purification of sprouted pulses amyalses and study its application in desizing of fabrics. Asian J Biochem Pharma Res. 2012, 3(2): 215-221.

[33] Rani K, Aqueous two phase purification of Vigna radaita amylase and its characterization. Int J Cur Pharm Rev \& Res. 2012, 3(3): 47-53.

[34] Rani K, Immobilization of Vigna radiate, Vigna mungo, Cicer arietinum (white) and Cicer arietinum (Black) amylases onto variety of activated fabrics. Int J Life Sci \& Pharma Res. 2012, 1(3): 124-133.

[35] Rani K, Mehta V, Preparation, Biodegradation of Coconut Oil Driven Chemically Modified Bovine Serum Albumin Microparticles of Encapsulated Cicer arietinum Amylase and Study of Their Application in Washing Detergents. Int. J. Pharm. Sci. Drug Res. 2014, 6(4): 351-355.

[36] Rani $\mathrm{K}$ and Jemamoni $\mathrm{K}$, Immobilization of vigna radiata $\beta$ amylase onto sodium treated and chlorinated woven bombyx mori silk fabric. IOSR J Pharmacy. 2012, 2(3): 512-519.

[37] Rani K and Saxsena S, Immobilization of phaseolus vulgaris amylase onto chemically charged woven bombyx mori silk fabric. Int J Current Res. 2012, 4(7): 5-6.

[38] Williams D F and Zhong S P, Biodeterioration/biodegradation of polymeric medical devices in situ. Int. Biodeter. Biodegradation.1994, 34: 95-130.

[39] Rani K, Production of amylase and alkaline phosphatise, Verlag:Lambert Academic Publishing Gmbh \& Co. KG, 2012,Germany

[40] Rani K. Emulsified Entrapment of Glycine Max B-amylase into Chemically Modified Bovine Serum Albumin and Study its Applications in Detergents. International Journal of Advanced Biotechnology and Research. 2012, 3(2): 591-595.

[41] Dubes A, Parrot-Lopez H, Abdelwahed W, Degobert G, Fessi H, Shahgaldian P, Coleman A, Scanning electron microscopy and atomic force microscopy imaging of solid lipid nanoparticles derived from amphiphilic cyclodextrins. European J Pharmaceutics \& Biopharmaceutics. 2003, 55(3): 279-282.

[42] Zhaoa X, Lva L, Pana B, Zhanga W, Zhanga S, Zhanga Q, Polymer-supported nanocomposites for environmental application: A review. Chem Engg J. 2011, 170(2-3): 381-394.

[43] Wykes J R, Dunnill P, Lilly M D, Immobilization of Alpha 
Amylase by attachment to soluble support materials. Biochimica et Biophysica Acta- Enzymology. 1971, 250: 522-529.

[44] Rani K, Immobilization of Vigna mungo $\beta$-amylase onto $\mathrm{NaCl}$ and $\mathrm{NaNO}_{3}$ treated woven Bombyx mori silk fabrics. Asian J Biol \& Life Sci. 2012, 1(2): 96-100.

[45] Rani K, Extraction and study of kinetic parameters of variety of sprouted pulses $\beta$-amylases. Int J Pharm and Life Sci. 2012, 3(8): 1895-1898

[46] Sharma K. R, Preparation of emulsified encapsulated nanoparticles of bovine serumalbumin of bound glucose oxidase and their application in soft drinks/non-alcoholic beverages. Biotechnol \& Biomaterials, 2012, 2(2): 1-4.

[47] Rani K, Comparative study of kinetic parameters of bacterial and fungal amylases. J Bio-Innovation, 2012, 3: 48-57.

[48] Müller GM, Leuenberger H and Kissel T. (1996). Albumin nanospheres as carriers for passive drug targeting: an optimized manufacturing technique. Pharm. Res. 13:32-37.

[49] Rani K, Rana R and Dutt S. Review on latest overview on proteases. Int J Current Life Sci, 2012, 2(1): 12-18.

[50] Rani K, Pant N and Chauhan C, Biodegradation of chemically modified egg albumin micropreparation for controlled release of bound vigna mungo amylase and their application in fabric desizing as cost effective bio-active preparation. Int J Pharma \& Bio Sci, 2015, 6(1): 1101-1111.

[51] Rani K, Applicative biodegradation study of egg albumin nanospheres by alkaline protease for release of encapsulated cicer arietinum amylase in washing as bio-active detergent additive. World J Pharmaceutical Res, 2015, 4(1): 1-13.

[52] Rani K, Goyal S and Chauhan C, Novel approach of alkaline protease mediated biodegradation analysis of mustard oil driven emulsified bovine serum albumin nanospheres for controlled release of entrapped Pennisetum glaucum (Pearl Millet) amylase. American J Advn Drug Delivery. 2015, 3(2): 135-148.

[53] Rani K, Gupta C and Chauhan C, Biodegradation of almond oil driven bovine serum albumin nanoparticles for controlled release of encapsulated Pearl millet amylase. American $J$ Phytomedicine Clin Therapeutics. 2015, 3(3): 222-230.

[54] Rani K, Chauhan C, Biodegradation of Cicer Arietinum Amylase loaded Coconut oil driven Emulsified Bovine Serum Albumin Nanoparticles and their application in Washing Detergents as Eco-Friendly Bio-Active Addictive, World Journal of Pharmacy and Pharmaceutical Sciences, 2014, 3(12): 924-936 